\title{
Evaluation of the Conservation Sites in Bozcaada Using the GAP Analysis Method
}

\author{
Merve Akbas (Corresponding author) \\ Canakkale Onsekiz Mart University, Graduate School of Natural and Applied Sciences, \\ Department of Landscape Architecture, Canakkale, Turkey \\ E-mail: merveakbas.comu@gmail.com \\ Tulay Cengiz Tasli \\ Canakkale Onsekiz Mart University, Faculty of Architecture and Design, \\ Department of Landscape Architecture, Canakkale, Turkey
}

\begin{abstract}
In Bozcaada, which is the subject of the research, the research area has been investigated with GAP analysis for the purpose of Systematic Conservation Planning for sustainability and biological diversity. Within the scope of GAP analysis method, field studies were carried out and some photographs of the area and biological facts were taken. The biological data of the area were compiled and their protection status was viewed. The data obtained were compiled and biotope map was procreated and life associations were determined. Subsequently, representative species were identified. After a clear determination of the protection aims, the protection system in the area was investigated and the gaps in the protection were determined. The gaps in the conservation system were replaced by the proposed conservation areas in line with the determined conservation objectives. For this purpose, conservation planning has been made with a systematic approach.
\end{abstract}

Keywords: Systematic Protection Planning, GAP Analysis, Bozcaada

DOI: $10.7176 / \mathrm{JSTR} / 5-7-07$

\section{GAP (Boşluk) Analizi Yöntemiyle Bozcaada'nın Korunan Alanlarının İrdelenmesi}

\begin{abstract}
Özet
Araştırmaya konu olan Bozcaada'da sürdürülebilirliğin ve biyolojik çeşitliliğin devamlılı̆̆ için Sistematik Koruma Planlaması amacı ile araştırma alanı GAP analiziyle irdelenmiştir. GAP (Boşluk) analizi yöntemi kapsamında arazi çalışmaları gerçekleştirilmiş, alan ve biyolojik unsurlara ait bazı fotoğraflar çekilmiştir. Alanın biyolojik verileri derlenmiş ve koruma statüleri incelenmiştir. Elde edilen veriler derlenerek biyotop haritası üretilmiş ve yaşam birlikleri tespit edilmiştir. Daha sonraki aşamada temsilci türler saptanmıştır. Koruma hedeflerinin net bir şekilde belirlenmesinden sonra alandaki koruma sistemi irdelenerek korumadaki boşluklar saptanmıştır. Koruma sistemi içerisindeki boşluklar yerini, belirlenen koruma hedefleri doğrultusunda öneri koruma alanlarına bırakmıştır. Bu amaçla sistematik bir yaklaşımla koruma planlaması yapılmıştır.
\end{abstract}

Anahtar Kelimeler: Sistematik koruma planlaması, GAP analizi, Bozcaada 


\section{Giriş}

Doğa koruma alanı biyolojik çeşitliliğin korunması ve devamlılığının sağlanması için doğal ve kültürel kaynaklarla bir bütün olarak düşünülen ve yasal yollarla koruma altına alınan doğal alanlardır (Phillips, 1998; Çetinkaya, 2003; Erduran ve Cirık, 2011). İnsan sağlığı ve yaşamın devamlılığı için, doğada yaşayan bitki ve hayvan türlerinin varlığı, onların yetişme ve yaşam ortamları ve belirli kriterler 1şığında korumaya değer bulunan doğa parçalarını ve doğal elamanları korumak şeklinde tanımlanmaktadır (Yücel, 1999, 2005; Yücel ve Babuş, 2005; Demirel, 2005; Sezer, 2015). Doğa korumanın en temel yaklaşımı olan korunan alanların önemli özelliği; türlerin tek tek korunması yerine çevresiyle beraber korunmasına olanak sağlamasıdır. Korunan alanların insan, bitki ve hayvan popülasyonları ve bu popülasyonların devamlılığı açısından önemi son derece büyüktür. $\mathrm{Bu}$ alanlar popülasyonların devamlılığını sağlarken ekosistemin ve biyolojik çeşitliliğin devamlılığı içinde önemli role sahiptirler. Ancak bu rolü yerine getirebilmek için yasal ve yönetsel birtakım sınırlamaların getirilmesi gerekmektedir.

Günümüzde korunan alan uygulamaları, ulusal ve bölgesel ölçeğin ötesinde, küresel koruma yaklaşımıyla ele alınmaya başlanmıştır. Bu bağlamda; uluslararası sözleşmeler ve kurumlar aracılığıyla bütüncül bir korunan alanlar ağının oluşturulması için ortak hedefler ve ölçütler belirlenmiştir. Biyolojik Çeşitlilik Sözleşmesi'nin getirdiği yaptırımlar ile IUCN tarafından ortaya konulan korunan alan kategorileri, bu konudaki uluslararası çerçeveyi belirleyen iki önemli kavram olarak karşımıza çıkmaktadır (Thomas, 2006; Artar, 2008).

Sağlıklı ve kapsamlı bir çevre koruma stratejisi, türlerin korunması, alanların korunması ve habitatların korunması unsurlarını içine alır. Bu unsurlar birbirini tamamlar niteliktedir (Yarar ve Magnin, 1997; Arı ve Derinöz, 2011). "Sistematik Koruma Planlaması (SKP)" bu unsurları içine alan bir yaklaşımla korumayı hedefler. SKP, kavramı kısaca koruma hedeflerinin açık bir şekilde tanımlandığı, biyolojik çeşitliliğin bütününün uzun vadede kalıcı bir şekilde temsil edildiği ve sadece korunan alanlarla sınırlı olmayan bir koruma yönetimi sistemi oluşturulma süreci olarak tanımlanabilir. Biyolojik ve sosyoekonomik veriler kullanılarak çalışılan bölge için bir koruma sistemi planlanır. Bunun için kullanılan biyolojik veriler; tür dağılım verileri, ekolojik yaşambirlikleri haritası, ekolojik ve evrimsel süreçler iken sosyo-ekonomik veriler ise; koruma yapmanın maliyeti, biyolojik çeşitliliği tehdit eden unsurlar ve koruma ve kalkınmayı birlikte gerçekleştirebilme firsatı oluşturur” (Zeydanlı, 2009; Turak ve ark., 2011). "SKP, boşluk analizi ve tamamlayıcılık yaklaşımını, katılımcı yaklaşımla irdeleyerek öncelikli koruma alanlarının oluşturulmasını hedefleyen bir metodolojidir. Bu metodoloji, vejetasyonun, fauna ve flora türlerinin, mevcut korunan alanların ve diğer ilgili verilerin haritalanması, tehdit analizinin, firsatların, sosyo-ekonomik verilerin irdelenmesi faaliyetlerini içerir" (T.C Tarım ve Orman Bakanlı̆̆ı, 2019). Boşluk analizi bir alanda henüz koruma altında olmayan ve koruma boşluğu oluşturan biyolojik çeşitlilik ögelerinin belirlenmesidir. Geliştirilecek koruma sistemi bu boşlukları doldurulacak şekilde planlanır. Tamamlayıcılık yaklaşımı ise en fazla sayıda biyolojik çeşitlilik ögesini, en az sayıda yerde koruma altına almayı hedefleyen bilgisayar uygulamalarına dayalı bir yaklaşımdır (Zeydanlı, 2009). Tamamlayıcılık, biyoçeşitlilik içeriğiyle ilgili birbirini tamamlayan alanlar kavramını ifade eder. Çok kriterli bir optimizasyon süreci ile birden fazla takson için koruma öncelikli alanları belirlemede tamamlayıcılık temelli yaklaşımlar (yaygın olarak Sistematik Koruma Planlaması) kullanılır (Margules ve Pressey, 2000; Cowling ve ark., 2003; Pierce ve ark., 2005; Zeydanlı ve ark., 2012).

SKP'nin aşamaları; planlama bölgesinin biyolojik çeşitliliği hakkındaki verilerin derlenmesi ve temsilci türlerin saptanması, planlama bölgesi için koruma hedeflerinin belirlenmesi, mevcut koruma alanlarının gözden geçirilmesi, ek koruma alanlarının seçilmesi, koruma eylemlerinin uygulanması (öncelikli koruma alanlarının belirlenmesi), korumanın sürekliliğinin sağlanması (koruma alanlarının yönetimi ve izlenmesi) olarak tanımlanmaktadır. (Margules ve Pressey, 2000; Groves ve ark., 2002; Zeydanlı, 2009; Turak ve ark., 2011).

Bu kapsamda araştırmaya konu olan Bozcaada'da sürdürülebilirliğin ve biyolojik çeşitliliğin devamlılığ1 için sistematik koruma planlamasını sağlamak amacıyla araştırma alanı GAP (Boşluk) analiziyle incelenmiştir.

\section{Materyal ve Yöntem}

Araştırma alanı olarak seçilen Çanakkale ilinin $38 \mathrm{~km}^{2}$ yüzölçümüne sahip olan Bozcaada ilçesi çalışmanın ana materyalini oluşturmaktadır (Şekil 1).

Bozcaada Türkiye'nin köyü olmayan tek ilçesidir. Bozcaada yüksek olmayan, basık ve hafif dalgalı bir topoğrafyaya sahiptir (Şekil 2). Ada'nın en yüksek noktasını teşkil eden Göztepe (192 m) yüksek görünümüyle dikkati çekmektedir. 




Şekil 1. Bozcaada'nın konumu

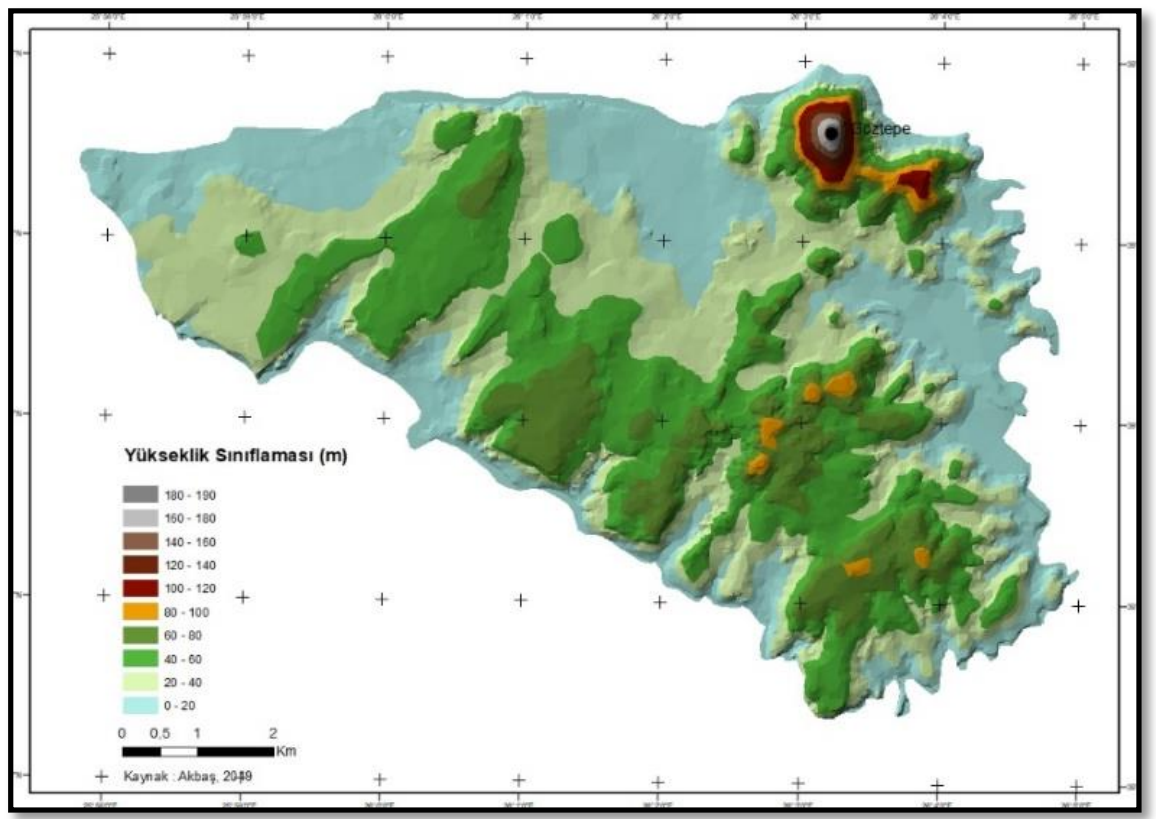

Şekil 2. Bozcaada’nın yükseklik sınıfları haritası

Ada'nın büyük bir bölümünün \% 0-6 arası eğime sahip olduğu görülmektedir (Şekil 3). oluşturur. Güney, güneydoğu ve kuzeydoğu kesimlerinde \% 6-12 arasında eğim hâkimken, bazı kıyı ve iç kesimlerde eğimin \% 12'den fazla olduğu görülmektedir. Güney kıyılarının bir kısmı ve Göztepe ve civarında \% 2030 arası eğim görülmektedir.

Ada tipik Akdeniz iklimine benzemekle birlikte, Çanakkale Boğazı'nın çıkışında bulunması nedeniyle kuzey rüzgârlarından oldukça etkilenmektedir. Yağışlar genellikle yağmur şeklinde görülmektedir (Seçmen ve Leblebici, 1978; Kaptan Ayhan, 2007; Yetim Erdinç, 2008). Tarım ve Orman Bakanlığ1 Meteoroloji Genel Müdürlüğünün 1980-2012 yılları arasında elde edilen 32 yıllık iklim verilerine göre; ortalama sıcaklık $15.5{ }^{\circ} \mathrm{C}$ 'dir. Ortalama rüzgâr hızı $6.1 \mathrm{~m} \mathrm{~s}^{-1}$ 'dir. Ada'nın dört mevsim rüzgârlı olmasından yararlanılarak enerji elde edilmektedir. Toplam yağış ortalaması ise 464.7 mm'dir. 


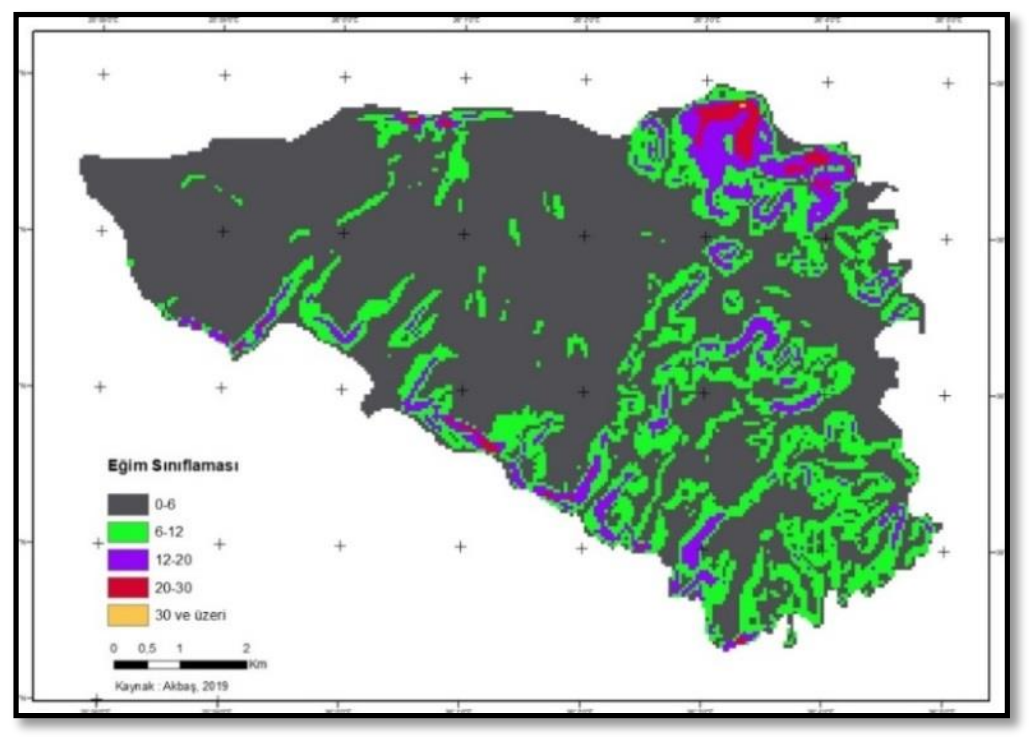

Şekil 3. Bozcaada'nın eğim sınıfları haritası

Ada'nın doğal bitki örtüsünde, maki formasyonu daha çok platolar bölgesinde ve nispeten eğimli vadi yamaçlarında ve Tuzburnu mevkinin güneyinde kalmıştır. Bozcaada' da çok dar bir alanda, Akdeniz ikliminin klimaks türü olan Pinus brutia (kızılçam)'ların meydana getirdiği ağaç formasyonuna da rastlanır (Hocaoğlu, 1985; Kaptan Ayhan, 2007; Doğan, 2011). Makinin tahrip edilmesinden sonra friganalar oluşur. Bozcaada'da çok geniş alanlar Sarcopoterium spinosum (abdestbozan, geven) tarafindan kaplanmıştır (Seçmen ve Leblebici,1978; Kaptan Ayhan, 2007).

Ada tarihsel değerler olarak potansiyel bir alandır. Tarihsel süreç içerisinde ilk sakinlerinin denizci ve tüccar olmalarından dolayı Pelazziler yani Akalar olduğu bilinmektedir (Aygen, 1985; Durmuş, 2006). Daha sonraları birçok medeniyete ev sahipliği yapmıştır. Çanakkale savaşları süresince Yunanistan işgalinde kalan Bozcaada 1923 yllında imzalanan Lozan Antlaşmasıyla Türkiye Cumhuriyeti'ne bırakılmıştır (Bamyacı, 2006; Kaptan Ayhan, 2007).

Bozcaada ilçe merkezinden oluşur ve köyü yoktur. "Önceleri kasaba merkezini Rum ve Türk Mahallesi olarak ikiye ayıran derenin yerinde günümüzde Çınar Çarşı Caddesi bulunmaktadır. Ada merkezi Cumhuriyet (Rum) ve Alaybey (Türk) Mahallesi olarak iki mahalleden oluşmaktadır. Cumhuriyet Mahallesinde Rum, Alaybey Mahallesinde Türk mimarisini yansitan yapılar mevcuttur" (Kaptan Ayhan, 2007; Doğan, 2011; T.C Bozcaada Belediyesi, 2019). Bozcaada'nın ilk nüfus sayımı Osmanlı döneminde 1831 yılında yapılmış ve bu sayımda nüfusun 1232 olduğu tespit edilmiştir. 1831-2018 yılları arasında genellikle artış gösteren nüfus, 1985 yllından itibaren 2000'li rakamlara geçmeye başlamıştır. Yaz aylarında ise bu nüfus turizm etkisiyle 10.000 'e yaklaştı̆̆ hatta geçtiği görülmektedir. Turizmin yarattı̆̆ 1 nüfus artışıyla tarihinde almadığı kadar insan nüfusunu barındırmaktadır.

Süregelen tarih boyunca Bozcaada'nın geçim kaynağı; balıkçılık, bağcılık ve buna bağlı olarak şekillenen şarapçılıktır. Süngercilik önceleri bir geçim kaynağ 1 iken, zor bir meslek olması ve denizlerde azalmasından ötürü son zamanlarda ekonomiye katkısı bulunmamaktadır. Bunun aksine turizm faaliyetleri son dönemlerde Bozcaada'nın ekonomisine oldukça katkı sağlamaktadır. Turizmle birlikte gelen ticari faaliyetler Ada halkının geçim kaynağı haline gelmiştir.

Bozcaada'nın doğal güzellikleri, kültürel yapısı ve birçok medeniyete ev sahipliği yapmış olması, bu değerlerin korunarak sürekliliğinin sağlanması amacıyla birtakım koruma çalışmaları yapılmıştır. Gayrimenkul Eski Eserler ve Anttlar Yüksek Kurulunun 1977 yılındaki kararları ile adada arkeolojik ve kentsel sit alanları tespit edilmiştir. Bozcaada'nın tamamı 14.10.1978 tarihinde Gayrimenkul Eski Eserler ve Anıtlar Yüksek Kurulu tarafindan III. derece doğal sit alanı olarak kabul edilmiştir. Tamamı III. derece doğal sit olan Bozcaada'da Kültür Varlıkları Koruma Kurulunun 23.11.1991 tarihli kararı ile I. Derece doğal sit alanı sınırları belirlenmiştir. Bozcaada'nın tamamı doğal sit statüsündedir. Ada genelinde, doğal sit, kentsel sit, arkeolojik sit alanları bulunmaktadır. Bozcaada'nın mevcut korunan alan varlığı Şekil 4 'de gösterilmiştir. 


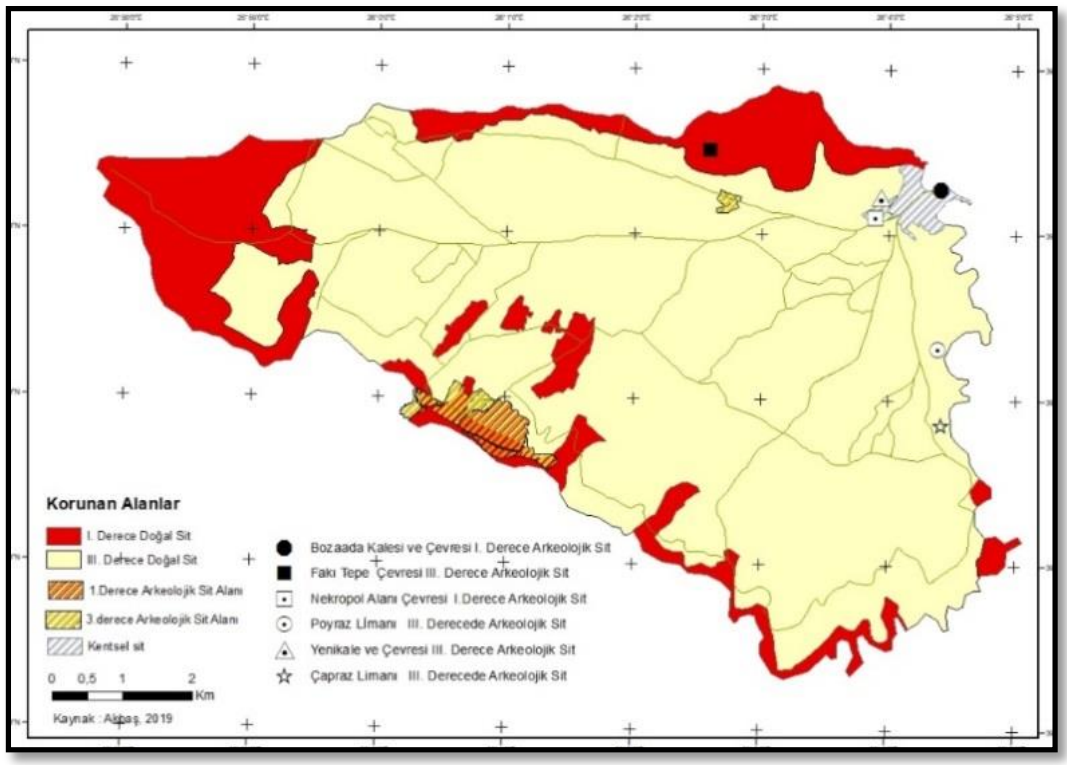

Şekil 4. Bozcaada'nın mevcut korunan alan varlığı

Araştırmada GAP (Boşluk) analizi yöntemiyle Sistematik Koruma Planlaması yapılmıştır. Araştırma alanı olarak seçilen Bozcaada'daki mevcut koruma alanları CBS tarafindan oluşturulan sayısal haritalar yardımıyla irdelenmiş ve alandaki eksiklikler saptanmıştır. Koruma boşluklarını doldurmak için mevcut korunan alanlar incelenerek kararlar analiz edilmiş ve koruma boşlukları "Boşluk Analizi”" ve "Tamamlayıcılık" yaklaşımı ile tanımlanarak "Sistematik Koruma Planlaması" yapılmıştır. Bu kapsamda, alana ait peyzajın doğal ve kültürel verilerinin analizleri yapılmıştır. Bu analizler sonucunda Ada'nın koruma statüsünde oluşan eksiklikleri saptanmış ve yeni öneri koruma statüleri getirilmiştir. Bu amaçla projede öncelikli koruma alanlarını belirlemede yapılacak aşamalar aşağıdaki gibi tanımlanmıştır:

1. Biyolojik çeşitliliğe ilişkin verilerin derlenmesi ve temsilcilerin saptanması

2. Koruma hedeflerinin belirlenmesi

3. Var olan koruma sistemindeki eksikliklerin saptanması ve boşluk analizi

4. Koruma Yönetimi için yeni alanların seçimi

\section{Biyolojik çeşitliliğe ilişkin verilerin derlenmesi ve temsilcilerin saptanması}

Ekolojik yaşam birlikleri ve tür dağılımları ve öncelikli türler belirlenmiştir. Endemik ve tehdit altında olan türlerin tehlike kategorilerinin belirlenmesinde Ekim ve ark., (2000) tarafindan hazırlanan Türkiye Bitkileri Kırmızı Kitabı ve IUCN kırmızı listesinden kaynak olarak yaralanılmıştır. Biyolojik çeşitliliğin saptanmasında biyotop haritası hazırlanmış ve tür dağılımlarının belirlenmesi çalışmaları yapılmıştır.

a) Ekolojik yaşam birlikleri (Biyotop) haritası üretilmesi aşamasında: Biyotop haritalamasında ekolojik yaşam birlikleri baz alınmıştır. Bu kapsamda 2012 Corine Arazi Örtüsü, Google Earth 2019 görüntüsü ile çakıştırılarak güncellenmiştir. Ayrıca bitki türleri yaşam birliklerinin tanımlanabilmesi için 2018 yılına ait Orman İl Müdürlüğü meşcere haritası, corine arazi örtüsü sınıflaması ile çakıştırılarak sayısal biyotop haritası üretilmiştir.

b) Tür dağılımlarının belirlenmesi aşamasında: Bitki ve hayvan varlığı incelenerek, 2018 yılına ait Orman İl Müdürlüğü meşcere haritasından yararlanılmıştır. Ayrıca arazi incelemelerinde bazı bitki türleri teşhis edilerek fotoğraflandırılmıştır. Flora ve faunanın tespitinde literatür incelemelerinden de yararlanılmıştır.

Araştırma alanında Önemli Alanlar (ÖA) ve temsilci türler belirlenirken, “Hassaslık” ve "Benzersizlik" kriterleri eşik değerler olarak nitelendirilmiştir.

Hassaslık kriterinde; Bozcaadaya ait IUCN'in kırmızı listesinde yer alan tehdit altında olan türler; kritik düzeyde tehlike altında olan türler (CR), tehlike altında olan türler (EN) ve hassas (VU) türler belirlenmiştir.

Benzersizlik kriterinde; dar yayılışlı bitkiler, geniş fakat kümelenmiş dağılıma sahip bitkiler, küresel öneme sahip yoğunlaşmalar vb. bitkiler belirlenmiştir. Ayrıca hayvan varlığında küresel, ulusal ölçekte öneme sahip türler incelenmiştir.

\section{Koruma hedeflerinin belirlenmesi}

Araştırma alanında biyoçeşitliliğin tümünü temsil ettiği düşünülen temsilcilerin belirli miktarda ya da 
oranda koruma sisteminin içinde olmasına dikkat edilmiştir. Temsiliyet koruma sistemleri için en önemli kriterlerden biri olup temsil edilmeyen biyolojik çeşitlilik unsurları koruma boşluğu olarak değerlendirilmiștir.

\section{Var Olan Koruma Sitemindeki Eksikliklerin Saptanması ve Boşluk Analizi}

Sistematik Koruma Planlamasının bu aşamasında mevcut koruma ağının temsiliyet özelliği incelenmiştir. Belirlenen biyolojik çeşitlilik hedeflerinin ne kadarı mevcut koruma sistemi içerisinde yer almaktadır, ne kadarı dışarıda kalmaktadır ve ne kadarı doğru bir oranda temsil edilmektedir incelenmiş̧tir. Mevcut koruma sisteminde yeterince temsil edilmeyen alanlar koruma boşluğu olarak nitelendirilmiştir.

\section{Koruma Yönetimi için yeni alanların seçimi}

Biyolojik çeşitlilik ve temsiliyet dereceleri dikkate alınarak, tamamlayıcılık ilkesi ile öneri koruma alanları belirlenmiştir. Bu aşamada mevcut koruma kararları temel alınarak incelenmiştir. Öneri boşluk koruma alanları belirlenirken habitat kayıplarının buna bağlı olarak da türlerin azalma riskleri dikkate alınmıştır. Parçalanmış habitatlar arasında ekolojik devamlllı̆̆1 ve ekosistem bütünlüğü, leke ve koridorların birbirleriyle bağlantısı kurularak sağlanmıştır.

\section{Bulgular}

Biyolojik çeşitliliğe ilişkin verilerin derlenmesi ve temsilcilerin saptanması aşamasında; 2012 Corine Arazi Örtüsü, Google Earth 2019 görüntüsü ile çakıştırılarak güncellenmiştir (Şekil 5).

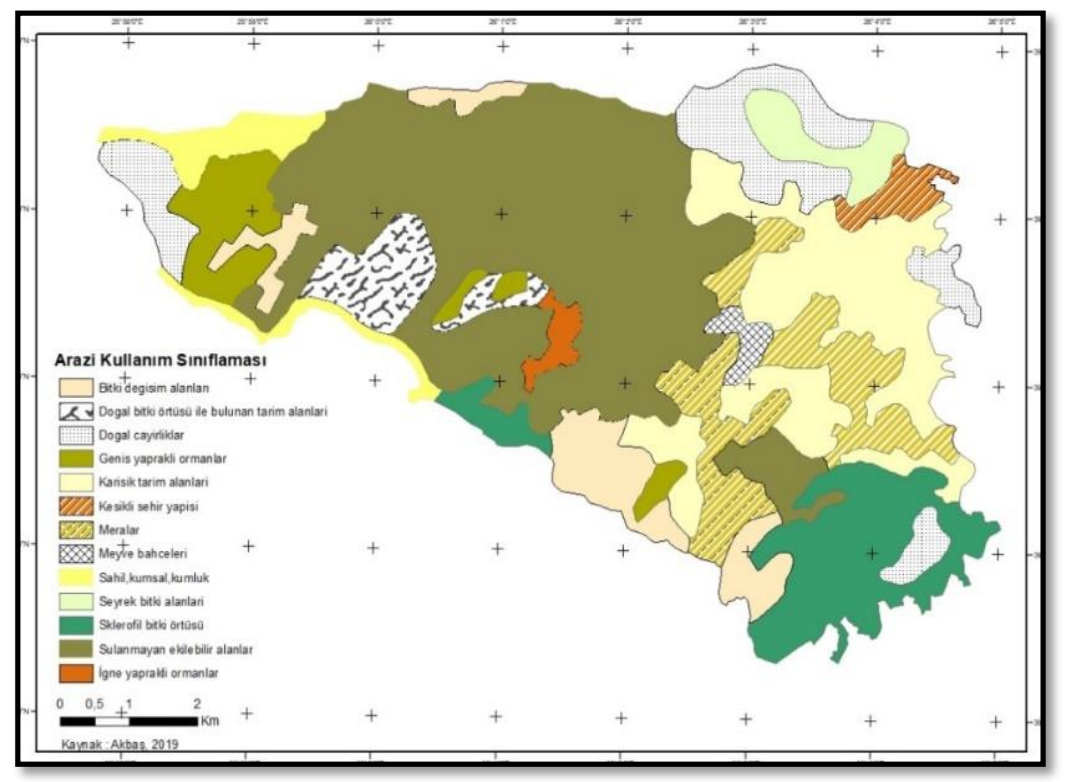

Şekil 5. Bozcaada’nın arazi kullanım sınıflaması

2012 yılına ait Corine arazi örtüsü sınıflaması ve 2018 yılına ait meşcere haritası incelendiğinde, Ada'nın orta kısımlarında baskın olarak görülen sulanmayan ekilebilir tarım alanları \% 35.37 ile arazi kullanımında en önemli yeri kapsamaktadır. Bunun dışında \% 14.06 ile karışık tarım alanları da Ada'nın doğusunda hâkim olmak üzere önemli yer kalamaktadır. \% 9.04 ile sklerofil bitki örtüsü Adada geniş yer kaplayan arazi kullanımındandır. Ada'nın büyük bir kısmın tarım arazisi (Z) olduğu görülmektedir. Orta kısımda yoğunlaşan Pinus brutia (kızılçam-Çz) ormanlarıyla birlikte küçük bir kısmında Quercus cerris (saçlı meşe-MI) biyotopu görülmektedir. Ada'nın güney kıyı kesiminde Pinus pinea (fistık çamı) ile birlikte görülen Quercus coccifera (kermes meşesi-Mkr) biyotopu küçük bir alanı kaplamaktadır. Meşcere haritasına göre mera alanları (Me) geniş alanlar kaplarken, güneydoğu kısmında yeni dikimi yapılmış Pinus pinea (fistık çamı) alanları yer almaktadır. Kent merkezi ise iskân alanlarını (İs) oluşturur. Ada'nın kıyı kesimlerinde çoğunlukla kayalık yarlar bulunmakla birlikte kumul alanlarda oldukça önemli yer kaplamaktadır. Özellikle batı (fener) burnunda bulunan kumul alan çift taraflı kompozisyonu açısından önemlidir ve ülkemizde nadir görülen yerler arasındadır (Karabacak ve ark., 2008; Avcıŏglu ve ark., 2015).

Ada'nın önemli bir kısmında ise tarım alanları ve özellikle de ekonomik değeri yadsınamayacak bağ alanları bulunmaktadır. Bozcaada'nın batı burnu Türkiye'nin 122 Önemli Bitki Alanından birisi olarak değerlendirilmiştir. Ada'da iki adet endemik tür bulunmakla birlikte bunlardan Papaver virchowii

54 I P a g e 
endemik bir tür olup, Türkiye'de birkaç il dışında Bozcaada'da Göztepe mevkinde doğal frigana örtüsü içinde bulunmaktadır. Geniş yayılımlı endemik bir türdür. Diğer bir endemik tür olan Dianthus ingoldbyi ulusal ve küresel ölçekte dar yayılıma sahip IUCN Kırmızı Listesinde "CR" kategoride kritik düzeyde tehlike altında olan bir türdür. Yapılan arazi çalışmalarında 3 lokalitesi plaj, 1 lokalitesi taş ocağı, 2 lokalitesi ise arkeolojik yapıların üzerinde olduğu için tehlikededir. Adada aynı zamanda Ayazma plajı yanındaki Zunguma burnunda kumullar da önemli biyotop alanıdır.

Yapılan fauna çalışmaları incelendiğinde biyoçeşitliliğin Çayır mevki, Göztepe, Yenikale, Fakı Tepe, Batıburnu, Ormanlık alanlar ve Poyrazliman bölgelerinde fazla olduğu görülür (Tosunoğlu ve ark., 2008; T.C Çevre ve Şehircilik Bakanlığı, 2016). Çayır bölgesinde bulunan Azmak deresinde Anguilla anguilla (Avrupa yılan balığı) türü tespit edilmiş olup bu tür IUCN kırmızı listesinde CR kategorisindedir, populasyon eğilimi ise azalan özelliktedir (Tosunoğlu ve ark., 2008; T.C Çevre ve Şehircilik Bakanlığı, 2016). Bozcaada'da 2 amfibi ve 14 sürüngen türü bulunmaktadır (Baran 1981; Tosunoğlu ve ark., 2008; Tosunoğlu ve ark., 2009; T.C Çevre ve Şehircilik Bakanlığı, 2016). Bu türlerden 2 deniz kaplumbağasının Çanakkale kıyılarında daha çok Saros Körfezi'nin çıkışında, Bozcaada ve Gökçeada arasında, Çardak Lagünü çevresinde, Çanakkale Boğazı'nın giriş ve çıkışında, Kumkale-Babakale açıklarında, Karabiga ve Nağara Burnu civarında kıyısal alanları beslenme, kışlama alanı olarak kullanabileceği sonucuna ulaşılmıştır. Bu çalışmada deniz kaplumbağalarının en çok görüldüğ̈ yerin Bozcaada olduğu sonucuna varılmıştır (Akdeniz ve ark., 2012; T.C Çevre ve Şehircilik Bakanlı̆̆ı, 2016). Özellikle kuzey kısımdaki tepeliklerde (Göztepe, Fakı Tepe, Yenikale) bütün türlere rastlanılmıştır (Tosunoğlu ve ark., 2008). Oryctolagus cuniculus (ada tavşanı) türü Ada'da bulunan memeli türlerindendir (Tosunoğlu ve ark., 2008; T.C Çevre ve Şehircilik Bakanlığı, 2016). Bozcaada; Ulusal Akdeniz Foku Komitesinin "Akdeniz Foku Koruma Alanları (MSPAs)" olarak fikir birliği yaptı̆̆ı ve türün Türkiye'de bulunduğu önemli alanlardan biridir. Bozcaada'da 103 kuş türü bulunmaktadır. Üzerinde daimi akışlı bir akarsuyun ve gölün bulunmaması karasal türlerin çoğunlukta görülmesinin sebebidir (Sevim, 2007; Tosunoğlu ve ark., 2008; T.C Çevre ve Şehircilik Bakanlığı, 2016). Merkezi yerleşim alanlarında Corvus monedula (küçük karga) ve Corvus corone (leş kargası) türlerinin sayısı oldukça fazla olduğu tespit edilmiştir (Tosunoğlu ve ark., 2008; T.C Çevre ve Şehircilik Bakanlığı, 2016). Araştırma sonucunda oluşturulan alanındaki tehdit altındaki türler Tablo 1'de gösterilmiştir.

Tablo 1. IUCN kategorisine göre alanda tehdit altındaki türler

\begin{tabular}{ll}
\hline IUCN & Flora ve Fauna türü \\
\hline LC & Papaver virchowii (Borcanka) \\
\hline CR & Dianthus ingoldbyi (Şehit karanfili) \\
\hline CR & Anguilla anguilla (Avrupa yılan balığı) \\
\hline VU & $\begin{array}{l}\text { Testudo graeca (adi tosbağa) } \\
\text { Caretta caretta (iribaş deniz kaplumbağası) }\end{array}$ \\
\hline EN & Chelonia mydas (yeşil deniz kaplumbağası) \\
\hline NT & Oryctolagus cuniculus (ada tavşanı) \\
\hline CR & Monachus monachus (akdeniz foku) \\
\hline NT & Falco vespertinus (Aladoğan) \\
\hline NT & Limosa limosa (çamur çulluğu) \\
\hline VU & Puffinus yelkouan (Yelkovan) \\
\hline
\end{tabular}

LC: En düşük derecede tehdit altında, CR: Kritik düzeyde tehlike altında, VU: Hassas,

EN: Tehlike altında olan, NT: Tehdite yakın

Ada'da yapılan arazi çalışmaları ve literatür taramaları sonucunda 448 bitki türü, 2 amfibi, 14 sürüngen türü, 11 memeli türü, 103 kuş türü teşhis edilmiştir (Tablo 2). Ada'nın bitki örtüsü ve ekosistem alanları olarak; maki-frigananın hâkim olduğu bitki örtüsüyle birlikte, kumul ekosistemi, çoğunlukla Pinus brutia' ların hâkim olduğu yer yer Pinus pinea (fıstık çamı)' ların da görüldüğü orman ekosistemi, kayalık ve çakıl habitatlar, tuzcul bataklıklar, Ada'yı çevreleyen denizel ekosistem biyoçeşitliliğin devamlılığını sağlayan yaşam alanları olarak da karşımıza çıkmaktadır. 
Tablo 2. Tür gruplarına göre Bozcaada'da yayılıș gösteren türlerin sayıları (IUCN, Türkiye kırmızı listesi’ne göre görülen toplam tüm türler, endemik türler, yayılım türleri, tehdit altındaki türler ve hedef

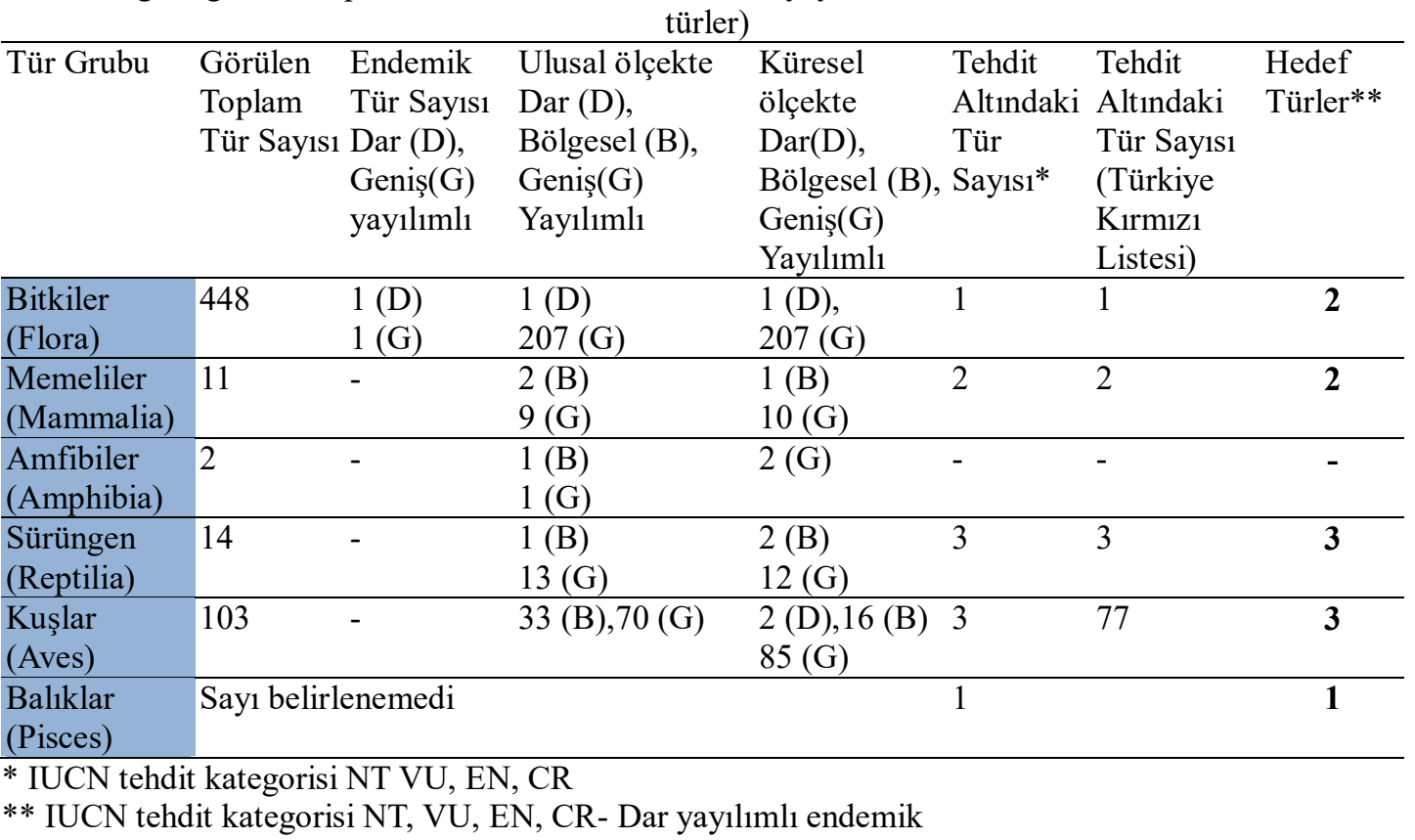

Çalışmada hedef türlerin seçiminde türlerin endemikliği, IUCN tehdit kategorisindeki yeri, bayrak tür veya şemsiye tür olma özellikleri dikkate alınmıştır. Hedef türlerin önceliklendirilmesinde yaygın olarak görülen veya yaşam alanı olarak seçicilik göstermeyen türler hedef tür listesine eklenmemiş, tehlike kategorisi yüksek, endemik (dar ve geniş yayılımlı), dar yayılım gösteren türler hedef tür listesine dahil edilmiştir.

Var olan koruma sistemindeki eksikliklerin saptanması ve boşluk analizinde; mevcut koruma sistemi ağına bakıldığında hedef tür olarak tespit edilen türlerin III. Derece doğal sit alanlarında geniş yayılım gösterdikleri, türlerin geniş yayılım gösterdikleri alanlarda habitat parçalanmalarının yaşandığ gözlemlenmiştir. Göztepe mevkisinde I. derece doğal sit olan alan içerisinde hedef fauna ve flora türlerine rastlanılmıştır. Ancak alan sınırları dışında kalan kısımda geniş yayılımlı endemik tür olan Papaver virchowii türü koruma sahası dışında kalmaktadır. İnsan etkisine yakın alanlarda olması bu türün tehlike oranını daha çok arttırmaktadır. Ada'nın batı burnu kumul alanında faunal hedef türlerinden Oryctolagus cuniculus (ada tavşanı) ve Testudo graeca (adi tosbağa) türlerine rastlanılmıştır. Bu türlerin hedef türler olmasından dolayı kesin koruma alan sınırları içerisine dahil edilmesi ve devamlılığının sağlanması gerekmektedir. IUCN kırmızı listesine göre "CR" kategoride olan Dianthus ingoldbyi mevcut koruma sistemi içerisinde bulunmaktadır.

Koruma hedeflerinin belirlenmesinde; türlerin ve diğer biyolojik çeşitlilik unsurlarının mevcut koruma sistemine dâhil edilen öneri koruma alanlarında herhangi biri dişarıda kalmayacak şekilde korunmuştur. Koruma yönetimi için yeni alanların seçiminde; var olan koruma sistemine ek yeni koruma alanlarının seçiminde biyolojik çeşitlilik unsurlarının devamlılığı dikkate alınarak, habitat kayıpları buna bağlı olarak da türlerin azalma riskleri dikkate alınmıştır. Parçalanmış habitatlar arasında ekolojik devamlılığ ve ekosistem bütünlüğü leke ve koridorların birbiriyle bağlantısı ile sağlanmıştır.

Şekil 6'da gösterilen mevcut ve öneri koruma alanları ile boşluğu doldurulmuş yeni koruma sistemi oluşturulmuştur. "Kesin korunacak alan", "Nitelikli doğal koruma alanı" ve "Sürdürülebilir koruma ve kontrollü kullanım alanı"nın oluşturulmasında biyolojik çeşitlilik içerisindeki tehlike kategorisi yüksek, endemik (dar ve geniş yayılımlı) ve dar yayılım gösteren türlerin varlığı önemsenmiştir. Ayrıca 19 Temmuz 2012 tarihinde Resmi Gazete'de yayınlanan “Korunan Alanların Tespit, Tescil ve Onayına İlişkin Usul ve Esaslara Dair Yönetmelik”te belirlenen esaslar dikkate alınmıştır. 


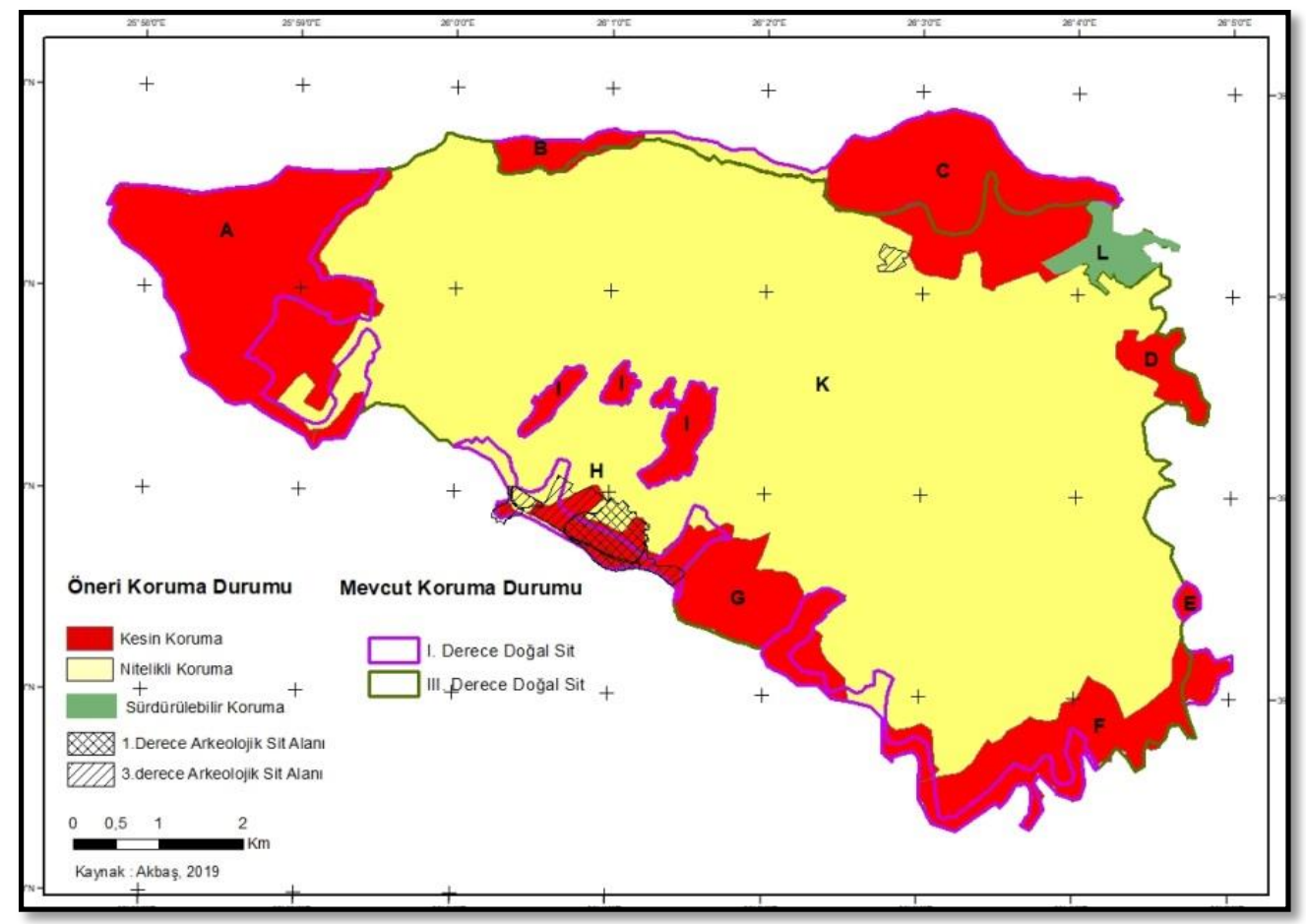

Şekil 6. Mevcut ve öneri koruma alanları

Şekil 6'da gösterilen haritada üzerinde alanlar A-L arasında harflendirilmiş ve koruma esasları aşağıda belirtilmiștir.

A: Mevcut hâliyle I. derece doğal sit olan alan statüsü korunarak kesin korunacak alan hâline dönüştürülmüş ve sınırları genişletilmiştir. Kritik türleri barındırması ve insan müdahalelerinden nispeten uzakta olduğu için kesin korunacak alanlardandır. Batı burnunda bulunan kumul alan çift taraflı kompozisyonu açısından önemlidir ve ülkemizde nadir görülen yerler arasındadır. Yine bu kısım Türkiye'nin 122 önemli bitki alanlarından biri olarak nitelendirilmektedir. Alanda tehdit altında flora elemanı bulunmazken, fauna elemanlarının yayılım alanlarına denk gelmektedir. Oryctolagus cuniculus (ada tavşanı) ve Testudo graeca (adi tosbağa) bu alanda geniş yayılım göstermektedir. Mevcut koruma alanındaki orman varlığı dikkate alınarak ve türlerin bu alanda habitat oluşturması açısından boşluklu olan mevcut koruma alanı orman alanına doğru genişletilmiş ve biyoçeşitliliğin sürekliliği sağlanmaya çalışılmışıtır. Alanın güney kıyı kesiminin mevcut koruma alanındaki iç çıkıntısı alan kullanımında tarım alanlarına denk geldiği için nitelikli doğal koruma alanı olarak nitelendirilmiştir.

B: Mevcut hâliyle I. derece doğal sit olan alan statüsü korunarak kesin korunacak alan hâline dönüştürülmüş ve sit sınırı doğu yönünde geri çekilmiştir. Geri çekilen alan tarım alanlarına denk geldiği için nitelikli doğal koruma alanı olarak korumaya devam edilmiştir. Kesin korunacak alan statüsündeki bu alan insan baskısından uzaktır ve corine arazi örtüsü sınıflamasına göre bitki değişim alanına denk gelmektedir.

C: Çalışma alanının en yüksek tepesini teşkil eden Göztepe'nin bulunduğu alandır. İnsan baskısından uzak olması, biyoçeşitlilik elemanlarına yaşama ortamı oluşturması ve hedef türlerin çoğunun burada lokalize olmasından dolayı, mevcut hâliyle I. derece doğal sit olan alan, statüsü korunarak kesin korunacak alan hâline dönüştürülmüş ve hedef türlerin dağılımları dikkate alınarak sit sınırı kuzey yönünde genişletilmiştir. Mevcut hâliyle Fakı Tepe çevresi IIII. derece arkeolojik sit alanını içermektedir. Geniş yayılımlı endemik tür olan Papaver virchowii (Borcanka) bu alanda doğal olarak bulunmaktadır.

D: Mevcut haliyle III. derece doğat sit alanı statüsündedir. Kapalı bir ekosistem olan Bozcaada da Poyraz limanı çevresinde biyoçeşitliliğin yoğunlaştığı gözlenmiştir. Corine arazi örtü sınıflamasına göre doğal çayırlıkları nitenlendiren alanda tarım alanları dikkate alınarak kesin korunacak alan olarak nitelendirilmiştir.

E: Mevcut haliyle I. derece doğat sit alanı olan alan, statüsü korunarak kesin korunacak alan hâline dönüştürülmüştür. Antropojenik etkiden uzak olan alanda son zamanlarda artan yapılaşmayı yasal boyutta frenlemek adına koruma çalışmalarına devam edilmiştir.

F: Mevcut hâliyle I. ve III. derece doğal sit alanlarını içeren alan fauna elemanlarından hedef türleri barındırır. Alanın tamamı kesin korunacak alan olarak nitelendirilirken, koruma sınırı kıyı habitatıyla 
bütünleşik hedef türleri içermesinden dolayı kıyı boyunca genişletilmiştir. Alan kullanımları ve mevcut yol güzergâhı dikkate alınarak kıyıdaki boşluklar kesin korunacak alan statüsüne dönüştürülmüştür.

G: Mevcut hâliyle I. ve III. derece doğal sit alanlarını içeren alan kıyısal habitatın korunması ve kıyı boyunca hedef türleri içermesinden dolayı, I. derece doğal sit olan alanlar ve kıyısal boşluk oluşturan alanlar kesin korunacak alan statüsüne dönüştürülmüștür. Mevcut hâliyle III. derece doğal sit alanına denk gelen alan, habitatın bütünlüğ̈̈, orman ekosisteminin devamlılı̆̆ı, kıyısal habitatın sürekliliğgi açısından kesin korunacak alan statüsündedir. Bu alanda alan kullanımları dikkate alınarak sınırlar belirlenmiştir.

H: Alan mevcutta I. ve III. derece arkeolojik sit alanlarını barındırır. Mevcut hâliyle genel olarak I. derece doğal sit statüsündedir. Alan statüsü korunarak kesin korunacak alan hâline dönüştürülmüştür. Arkeolojik alan sınıları ve alan kullanımları dikkate alınarak Zunguma Burnu'nun kuzeyi kesin korunacak alan statüsünden, nitelikli doğal koruma alanı statüsüne dönüştürülmüştür. Ayazma plajını içeren kısım var olan koruma statüsünde insanların turizm faaliyetlerine olanak sağladığ için kesin korunacak alan statüsünden nitelikli doğal koruma alanı olarak nitelendirilmiştir. Doğal yapısını gerçekleșen turizm faaliyetlerine nazaran koruyan, kıyı habitatları ile bütünleșik, hedef türlere yaşam alanı oluşturduğu için kıyı kesimleri kesin korunacak hassas alan olarak nitelendirilmiştir. Bu alanda yoğun turizm faaliyetlerinin oluşturacağı olumsuz etkilerin minimum düzeye inmesi amaçlanmış ve statüler bu amaçla belirlenmiştir. Zunguma Burnu'nu içeren alan ulusal ve küresel ölçekte dar yayılıma sahip Dianthus ingoldbyi türünü barındırır. Alan genel olarak hedef fauna türlerini barındırdığı için Ada'nın kuzey kıyıları boyunca boşluk koruma alanları belirlenerek, kıyı habitatının ve biyoçeşitliliğin devamlılı̆ğ sağlanmıştır.

I: Mevcut koruma statüsünde I. derece doğal sit alanı olan alan, statüsü korunarak kesin korunacak alan hâline dönüştürülmüştür. Meşcere haritası dikkate alındığında Pinus brutia ormanlarının hâkim olduğu görülmektedir. Bu alan orman ekosistemi oluşturduğundan fauna elemanları için doğal yaşam alanları oluşturmaktadır. Ekosistem içerisinde hedef fauna türlerini barındırmakta, antropojenik faaliyetlere uzak ve büyük ölçüde doğal yapıya sahip bir alandır. Bu üç alanın çevresi tarım alanlarıyla çevrili olduğu için, çevresi nitelikli doğal koruma alanı olarak değerlendirilmiştir.

K: Mevcut koruma statüsünde III. derece doğal sit alanı olan alan, nitelikli doğal koruma alanına dönüşsürülmüştür. Alan genel olarak bağ alanlarını ve diğer tarım alanlarını içerdiği için nitelikli doğal koruma alanı statüsünde değerlendirilmiştir. Seyrek yapıda yerleşimin görüldüğü bu alanlarda doğal yapı kısmen korunmuş ve fauna bakımından hedef türlere rastlanılmıştır. Alan kıyı habitatlarıyla bütünleşik yapıda olduğu için koruma çalışmalarında önem arz etmektedir.

L: Ada'nın merkezini oluşturan bu alan, yapı alanları, turistik tesisler ve diğer kullanım alanlarının yoğun olarak görüldüğü alandır. Bu alanda doğal yapıyı geriye dönüştürmek kısmen mümkün olmasada diğer habitat alanlarıyla bütünleşik ve etkileşim halinde olmasından dolayı sürdürülebilir koruma ve kontrollü kullanım alanı nitelendirilmiştir.

\section{Sonuç ve Tartışma}

Koruma çalı̧̧masında genel olarak tarım alanlarının bulunduğu alanlar kesin korunacak alan statüsünden nitelikli doğal koruma alanı statüsüne dönüştürülmüştür. Mera ve tarım alanları kesin korunacak alan statüsünün dışında bırakılmış ve nitelikli doğal koruma alanı olarak nitelendirilmiştir.

Kesin korunacak alanlar tayin edilirken; bölgesel, ulusal veya dünya ölçeğinde olağanüstü ekosistemleri, türleri bulundurmaları, insan etkisinden uzak olmaları, korunacak hedef tür veya türlerin üreme alanlarını içermesi, jeolojik, jeomorfolojik özelliklerinin korunmuş olmasına dikkat edilmiştir. $\mathrm{Bu}$ kriterlerden bir veya birkaçını içeren alanlar kesin korunacak alanlar olarak değerlendirilmiştir.

Nitelikli doğal koruma alanları tayin edilirken; önemli ölçüde insan faaliyetleri tarafindan etkilenmemiş olması, doğal alanların ekolojik bütünlüğünü sağlaması, aşırı derecede ve uygunsuz insan kullanımı ve mevcudiyetinden uzak olması, korunacak hedef tür veya türlerin yıl içerisinde dönemlerine bağlı yaptıkları göç ve yayılma alanlarını ve göç yollarını ihtiva etmesine dikkat edilmiştir. Bu kriterlerden bir veya birkaçını içeren alanlar nitelikli doğal koruma alanı olarak değerlendirilmiştir.

Sürdürülebilir koruma ve kontrollü kullanım alanları tayin edilirken; kesin korunacak alanlar veya nitelikli doğal koruma alanlarını etkilemesi, bu koruma bölgeleri ile bütünlük göstermesi, korumaya katkı sağlaması, doğal ve kültürel bakımdan uyumlu düşük yoğunlukta faaliyetleri içermesi, turizm ve yerleşimlere izin vermesi, ulusal, bölgesel ve yerel seviyelerde doğal kaynakların sürdürülebilir kullanımına ve kalkınmaya destek olmasına dikkat edilir. Bu kriterlerden bir veya birkaçını içeren alanlar sürdürülebilir koruma ve kontrollü kullanım alanları olarak değerlendirilmiştir.

Yapılan diğer koruma çalışmalarından (Zafer, 1991; Yetim Erdinç, 2008; Vuruşkan, 2009) farklı olarak 2012 yılında Resmi Gazete'de yeni koruma statü kararlarının alınması araştırmalarda koruma statülerinin değerlendirilmesinin farklılaşmasına neden olmuştur (T.C Çevre ve Şehircilik Bakanlığı, 2016b; Ankaya,

58 I P a g e 
2018; Çelik, 2018). Bozcaada'da gerçekleştirilen bu çalışma daha önce Çevre ve Şehircilik Bakanlığı'nca (2016b) yapılan Çanakkale İli Doğal Sit Alanlarının Ekolojik Temelli Bilimsel Araştırma Projesi ile paralellik göstermekte olup yeni kriterlere göre çalışma kapsamında yeniden değerlendirilmiştir. Ancak söz konusu araştırmada sadece doğal alanların sit kararları dikkate alınmıştır. Yapılan bu araştırmada farklı olarak, doğal peyzaj özelliklerinin yanı sıra koruma kararlarında çok önemli olan kültürel peyzaj özellikleri de dikkate alınarak değerlendirilmiştir. Doğal ve kültürel özelliklerin birlikte değerlendirilmesi koruma kararlarının daha sağlıklı olmasını sağlamıştır. Yoğun kullanıma maruz kalan Bozcaada'nın yeni tanımlanan kriterlere göre bütünsel olarak değerlendirilmesi araştırmanın orijinalliğini sağlamıştır.

Araştırmada kullanılan boşluk analizi çalışmaları ülkemizde ve diğer ülkelerde koruma alanlarında oluşan boşlukları doldurmak amacıyla uygulanmaktadır (Langhammer et al., 2007). Önemli Doğa Alanlarını (ÖDA) tanımlama, önceliklendirme ve ÖDA temelli boşluk analizi çalışmaları, ülkelerin biyolojik çeşitliliğinin korunması için küresel boyutta önem taşımaktadır. Bu alanların, yerel ölçekte uygulanabilir standartlar doğrultusunda belirlenmesinin gerekliliği dikkate alınarak mekansal analizlerle koruma kararlarının alınması sürdürülebilirlik için önemlidir.

Not: Bu makale Prof. Dr. Tülay Cengiz Taşlı danışmanlı̆̆ında, Merve Akbaş tarafından yapılan yüksek lisans tezi kapsamında yazılmıştır. Tezde bitki çalışmalarında yardımcı olan Sayın hocamız Doç. Dr. Ersin Karabacak'a çok teşekkür ederiz.

\section{Kaynaklar}

Akdeniz, B., Yalçın Özdilek, Ş., Okur, E., \& Gürsoy, S. (2012). Çanakkale Kıyılarının Deniz Kaplumbağalarının (Caretta Caretta ve Chelonia Mydas) Yaşama Alanı Olarak Değerlendirilmesi. Anadolu Doğa Bilimleri Dergisi, 3(1): 37-45.

Ankaya, F. (2018). İzmir İli Çeşme İlçesi Doğal Sit Alanlarının Peyzaj Kriterleri Bağlamında İncelenmesi. Ege Üniversitesi, Fen Bilimleri Enstitüsü, Peyzaj Mimarlığı Anabilim Dalı, Doktora Tezi, İzmir.

Arı, Y., \& Derinöz, B. (2011). Bir Sulak Alan Nasıl Yönetilmez? Kültürel Ekolojik Perspektif ile Marmara Gölü (Manisa) Örneği. Coğrafi Bilimler Dergisi, 9 (1): 41-60.

Artar, M. (2008). Karatepe-Aslantaş Milli Parkı Örneğinde Korunan Alanlar İçin Bir İzleme Yönteminin Geliştirilmesi. Çukurova Üniversitesi, Fen Bilimleri Enstitüsü, Peyzaj Mimarlığı Anabilim Dalı, Doktora Tezi, Adana.

Avcıŏglu, M., Erginal, A.E., Öztürk, M.Z., Demirci, A., Ekinci, Y.L., Türkeş, M., Karabacak, E., Sungur, A., Özcan, H., Ekinci, R., \& Erginal, G. (2015). Physico-Chemical Features and Subsurface Nature of Coastal Dunes on Bozcaada Island, NW Turkey. International Journal of Environment and Geoinformatics 2(1): 1-15.

Aygen, M.S. (1985). Bütün Yönleriyle Bozcaada. Türkeli Yayınları No:12,Türkeli Matbaası, Afyon.

Bamyacı, A.O. (2006). Antik Dönem Denizciliğinde Tenedos/Bozcaada: Kıyısal Kullanım ve Ticaret. Çanakkale Onsekiz Mart Üniversitesi, Sosyal Bilimler Enstitüsü, Arkeoloji Anabilim Dalı, Yüksek Lisans Tezi, Çanakkale.

Baran, İ. (1981). Kuzey Ege denizi, Marmara denizi ve Karadeniz'deki Adalarımızın Herpetofaunasının Taksonomik ve Ekolojik Araştırılması. Doğa Bilim Dergisi, Temel Bilim 5: 155-162. , Ankara. 
Cowling, R.M., Pressey, R.L., Sims-Castley, R., le Roux, A., Baard, E., Burgers, C.J., \& Palmer, G. (2003). The Expert or The Algorithm? Comparison of Priority Conservation Areas İn The Cape Floristic Region İdentified By Park Managers And Reserve Selection Software. Biological Conservation, 112 (1-2): 147-167.

Çelik, Ö. F. (2018). Doğal Sit Alanlarının Korunması ve Yönetiminde Coğrafi Bilgi Sistemlerinin Rolü. Erciyes Üniversitesi, Fen Bilimleri Enstitüsü, Harita Mühendisliği Anabilim Dalı, Yüksek Lisans Tezi, Kayseri.

Çetinkaya, G. (2003). Doğa Koruma Alanları ve Biyosfer Rezerv. Kırsal Çevre Yı1lığı, Kırsal Çevre ve Ormancılık Sorunları Araştırma Derneği: 32-40, Ankara.

Demirel, Ö. (2005). Doğa Koruma ve Milli Parklar. Karadeniz Teknik Üniversitesi, Orman Fakültesi Genel Yayın No: 219, Fakülte Yayın No: 37, Trabzon, 424 s.

Doğan, M. (2011). Beşeri Coğrafya Açısından Bozcaada. Anadolu Ofset, İstanbul, 187 s.

Durmuş, H. (2006). Bozcaada'nın Sosyo- Ekonomik Yapısı ve Kültürü. Osmangazi Üniversitesi, Sosyal Bilimler Enstitüsü, Tarih Anabilim Dalı, Türkiye Cumhuriyeti Tarihi bilim Dalı, Yüksek Lisans Tezi, Eskişehir.

Ekim, T., Koyuncu, M., Vural, M., Duman, H., Aytaç, Z., \& Adıgüzel, N. (2000). Türkiye Bitkileri Kırmızı Kitabı. Türkiye Tabiatını Koruma Derneği, Ankara, ix+246 s.

Erduran, F., \& Cirık, U. (2011). Gelincik Dağı Tabiat Parkı'nın Rekreasyonel Peyzaj Değerlerinin Belirlenmesi. Ankara Üniversitesi Ziraat Fakültesi Dergisi, 42 (1): 63-77.

Groves, C.R., Jensen, D.B., Valutis, L.L., Redford, K.H., Shaffer, M.L., Scott, J.M., Baumgartner, J.V. Higgins, J.V., Beck, M.W., \& Anderson, M.G. (2002). Planning for Biodiversity Conservation: Putting Conservation Science İnto Practice. BioScience, 52(6): 499-512 pp.

Hocaoğlu, Ş. (1985). Bozcaada’nın Fiziki Coğrafyası. Ege Coğrafya Dergisi, 3 (1): 175-199.

Kaptan Ayhan, Ç. (2007). Özgün Peyzaj Karakteristiklerine Sahip Mekanlara Yönelik Bir Peyzaj Planlama Yönteminin Ortaya Konulması; Bozcaada Örneği. Ege Üniversitesi, Fen Bilimleri Enstitüsü, Peyzaj Mimarlığı Anabilim Dalı, Doktora Tezi, İzmir.

Karabacak, E., Erginal, A.E., \& Özmen, H. (2008). Bozcaada-Batıburnu Kumulu Florası ve KumulVejetasyon Haritalaması. Bozcaada (Çanakkale): Çanakkale Bozcaada Değerleri Sempozyumu Bildirileri Kitabı, 183-191.

Langhammer, P.F., Bakarr, M.I., Bennun, L.A., Brooks, T.M., Clay, R.P., Darwall,W., De Silva, N., Edgar, G.J., Eken, G., Fishpool, L.D.C., Fonseca, G.A.B. da, Foster, M.N., Knox, D.H., Matiku, P., Radford, E.A., Rodrigues, A.S.L., Salaman, P., Sechrest, W., \& Tordoff, A.W. (2007). Identification and Gap Analysis of Key Biodiversity Areas: Targets for Comprehensive Protected Area Systems. Gland, İsvicre: IUCN. Çev: Doğa Derneği (2008). Önemli Doğa Alanları' nın Boşluk Analizi ve Belirlenmesi: Kapsamlı Korunan Alanlar Ağı Sistemi İçin Hedefler.

Margules, C.R., \& Pressey, R.L. (2000). Systematic conservation planning. Nature, 405: 243-253.

Phillips, A. (1998). Biosphere Reserves and Protected Areas: What is the Difference? Biosphere reserves - myth or reality? Proceedings of a workshop on biosphere reserves, World Conservation Congress. Montreal, 1996, Gland: IUCN ,1998. P. 7-10. 
Pierce, S.M., Cowling, R.M., Knight, A.T., Lombard, A.T., Rouget, M., \& Wolf, T. (2005). Systematic conservation planning products for land-use planning: interpretation for implementation. Biological Conservation. 125 (4): 441-458.

Seçmen, Ö., \& Leblebici, E. (1978). Gökçeada ve Bozcaada Adalarının Vejetasyon ve Florası IVejetasyon ve Bitki Toplulukları. Bitki Dergisi, 5 (2): 195-269.

Sevim, İ. (2007). Çanakkale Adaları Kuş Populasyonları ve Habitat İlişkileri Üzerine Gözlemler. Çanakkale Onsekiz Mart Üniversitesi, Fen Bilimleri Enstitüsü, Biyoloji Anabilim Dalı, Yüksek Lisans Tezi, Çanakkale.

Sezer, İ. (2015). Koç Kayası Tabiat Parkı'nın Ekoturizm Olanakları Açısından Değerlendirilmesi. Karadeniz Sosyal Bilimler Dergisi, 7 (12): 172-207.

T.C Bozcaada Belediyesi, (2019). Bozcaada Hakkında. http://www.bozcaada.bel.tr/bozcaada/bozcaada-hakkinda/

T.C Çevre ve Şehircilik Bakanlığı, (2016). Gökçeada ve Bozcaada Tarım Master Planı SÇD Pilot Projesi - SÇD Final Raporu .

T.C Çevre ve Şehircilik Bakanlığı, (2016b). Çanakkale İli Doğal Sit Alanlarının Ekolojik Temelli Bilimsel Araştırma Projesi Sonuç Raporu. (Yayınlanmamış).

T.C Tarım ve Orman Bakanlığı, (2019). Sistematik Koruma Planlaması (SKP) Yöntemi. http://natura2000.ormansu.gov.tr/tr/natura-2000/

Thomas, L. (2006) .Türkiye Korunan Alan Yönetiminde IUCN Kategori Sistemi. Çevre ve Orman Bakanlığı. Doğa Koruma ve Milli Parklar Genel Müdürlüğü. Biyolojik Çeşitlilik ve Doğal Kaynak Yönetimi Projesi.

Tosunoğlu, M., Gül, Ç., \& Uysal, İ. (2008). Bozcaada'nın Omurgalı Faunası (Balıklar, Kurbağalar, Sürüngenler, Kuşlar ve Memeliler). Çanakkale İli Değerleri Sempozyumları (25-31 Ağustos 2008). Bozcaada değerleri Sempozyumu, 208-215.

Tosunoğlu, M., Gül, Ç., \& Uysal, İ. (2009). "The herpetofauna of Tenedos (Bozcaada, Turkey)". Herpetozoa, $22(1 / 2) .75-78$

Turak, A., Balkız, Ö., Ambarlı, D., Durmuş, M., Özkil, A., Yalçın, S., Özüt, D., Kınıkoğlu, Y., Meydan Kocaman, T., Cengiz, S., Albayrak, F., Kurt, B., Zeydanl, U., \& Bilgin C. (2011). Karadeniz Bölgesi Sistematik Koruma Planlaması. Ankara. Doğa Koruma Merkezi.

Vuruşkan, A. (2009). Antalya Kentindeki Doğal Sit Alanlarına İlişkin Sorunların İrdelenmesi. Akdeniz Üniversitesi, Fen Bilimleri Enstitüsü, Peyzaj Mimarlığı Anabilim Dalı, Yüksek Lisans Tezi, Antalya.

Yarar, M., \& Magnin, G. (1997). Türkiye’nin Önemli Kuş Alanları. Doğal Hayatı Koruma Derneği, İstanbul.

Yetim Erdinç, L. (2008). Gökçeada ve Bozcaada'nın Doğal ve Kültürel Peyzaj Özelliklerinin Belirlenmesi Koruma ve Geliştirme Olanakları. Ankara Üniversitesi, Fen Bilimleri Enstitüsü, Peyzaj Mimarlığı Anabilim Dalı, Doktora Tezi, Ankara.

Yücel, M. (1999). Doğa Koruma Alanları ve Planlaması (2). Çukurova Üniversitesi, Ziraat Fakültesi Genel Yayın No: 104, Yardımcı Ders Kitapları Yayın No: B-9, Adana, 255 s. 
Yücel, M. (2005). Doğa Koruma. Çukurova Üniversitesi, Ziraat Fakültesi Genel Yayın No: 265, Yardımcı Ders Kitapları Yayın No: A-85, Adana, $430 \mathrm{~s}$.

Yücel, M., \& Babuş, D. (2005). Doğa Korumanın Tarihçesi ve Türkiye'deki Gelişmeler. Doğu Akdeniz Ormancılık Araştırma Müdürlüğü DOA Dergisi, Sayı: 11; S: 151 - 175.

Zafer, B. (1991). Türkiye'de Doğa Koruma Alanları ve Doğal Sitlerin Belirleme ve Sinıflandırılmasında Kullanılacak Kriterlerin Saptanması Amacıyla İzmir/ Kemalpaşa Örneklemesine Dayalı Yöntem Araştırması. Ege Üniversitesi, Fen Bilimleri Enstitüsü, Peyzaj Mimarlığı Anabilim Dalı, Doktora Tezi, İzmir.

Zeydanlı, U. (2009). Sistematik Koruma Planlaması ve Türkiye'deki Uygulamalar. Akay, A., \& Demirbaş Özen, M., Ed. Peyzaj Yönetimi Kitabı İçinde, Ankara, 179-203.

Zeydanlı, U.S., Turak, A.S., Balkız, Ö., Özüt, D., Ertürk, A., Welch, H., Karaçetin, E., Ambarlı, D., Durmuş, M., \& Bilgin, C. C. (2012). Identification of Prime Butterfly Areas in Turkey using systematic conservation planning: Challenges and opportunities. Biological Conservation, 150 (1): $86-93 \mathrm{pp}$. 